
Hellenistic Culture and Society

General Editors: Anthony W. Bulloch, Erich S. Gruen, A. A. Long, and Andrew F. Stewart

I. Alexander to Actium: The Historical Evolution of the Hellenistic Age, by Peter Green

II. Hellenism in the East: The Interaction of Greek and Non-Greek Civilizations from Syria to Central Asia after Alexander, edited by Amélie Kuhrt and Susan Sherwin-White

III. The Question of "Eclecticism": Studies in Later Greek Philosophy, edited by J. M. Dillon and A. A. Long

IV. Antigonos the One-Eyed and the Creation of the Hellenistic State, by Richard A. Billows

V. A History of Macedonia, by R. Malcolm Errington, translated by Catherine Errington

VI. Attic Letter-Cutters of 229 to 86 B.C., by Stephen V. Tracy

VII. The Vanished Library: A Wonder of the Ancient World, by Luciano Canfora

VIII. Hellenistic Philosophy of Mind, by Julia Annas

IX. Hellenistic History and Culture, edited by Peter Green

X. The Best of the Argonauts: The Redefinition of the Epic Hero in Book One of Apollonius's Argonautica, by James J. Clauss

XI. Faces of Power: Alexander's Image and Hellenistic Politics, by Andrew Stewart

XII. Images and Ideologies: Self-definition in the Hellenistic World, edited by A. W. Bulloch, E. S. Gruen, A. A. Long, and A. Stewart

XIII. From Samarkhand to Sardis: A New Approach to the Seleucid Empire, by Susan Sherwin-White and Amélie Kuhrt

XIV. Regionalism and Change in the Economy of Independent Delos, 314-167 B.C., by Gary Reger

XV. Hegemony to Empire: The Development of the Roman Imperium in the East from 148 to 62 B.C., by Robert Kallet-Marx

XVI. Moral Vision in the Histories of Polybius, by Arthur M. Eckstein

XVII. The Hellenistic Settlements in Europe, the Islands, and Asia Minor, by Getzel M. Cohen

XVIII. Interstate Arbitrations in the Greek World, 337-9o B.C., by Sheila L. Ager

XIX. Theocritus's Urban Mimes: Mobility, Gender, and Patronage, by Joan B. Burton

XX. Athenian Democracy in Transition: Attic Letter-Cutters of 340 to 290 B.C., by Stephen V. Tracy

XXI. Pseudo-Hecataeus, On the Jews: Legitimizing the Jewish Diaspora, by Bezalel Bar-Kochva

XXII. Asylia: Territorial Inviolability in the Hellenistic World, by Kent J. Rigsby

XXIII. The Cynics: The Cynic Movement in Antiquity and Its Legacy, edited by R. Bracht Branham and Marie-Odile Goulet-Cazé 
XXIV. The Politics of Plunder: Aitolians and their Koinon in Early Hellenistic Era, 279-2I7 B.C., by Joseph B. Scholten

$\mathrm{XXV}$. The Argonautika by Apollonios Rhodios, translated, with introduction, commentary, and glossary, by Peter Green

XXVI. Hellenistsc Constructs: Culture, History, and Historiography, edited by Paul Cartledge 

The Cynics

$\longrightarrow$ 



\section{The Cynics}

The Cynic Movement in Antiquity and Its Legacy

Edited by R. Bracht Branham and Marie-Odile Goulet-Cazé

University of California Press

Berkeley / Los Angeles / London 
University of California Press

Berkeley and Los Angeles, Calif.

University of California Press, Ltd.

London, England

(C) I 996 by

The Regents of the University of California

Library of Congress Cataloging-in-publication Data

The Cynics : the cynic movement in antiquity and its legacy / edited

by R. Bracht Branham and Marie-Odile Goulet-Cazé.

p. $\quad \mathrm{cm}$. - (Hellenistic culture and society ; 23)

Includes bibliographical references and index.

ISBN 0-520-20449-2 (alk. paper)

I. Cynics (Greek philosophy) I. Branham, Robert

Bracht.

II. Goulet-Cazé, Marie-Odile. III. Series.

B508.C94 1997

I $83^{\prime} \cdot 4-\mathrm{dc} 20$

96-20375

CIP

Printed in the United States of America

987665432 I

The paper used in this publication meets the minimum requirements of American National Standard for Information Sciences - Permanence of Paper for Printed Library Materials, ANSI Z39-48-I984. 